\title{
PENGARUH KONSENTRASI EKSTRAK DAUN KELOR TERHADAP PERTUMBUHAN DAN HASIL TANAMAN SELADA (Lactuca sativa L.) DI KABUPATEN JAYAWIJAYA
}

\author{
Anti Uni Mahanani ${ }^{1}$, Lemira Kogova ${ }^{2}$ \\ ${ }^{1,2}$ Program Studi Agroteknologi STIPER Petra Baliem Wamena \\ Email: mahanani@gmail.com
}

Receive: 20 Juli 2018

Accepted: 5 Oktober 2018

\begin{abstract}
Vegetables are one of the agricultural products that are needed and this annual crop is a plant that is generally relatively little time to plant. Of the various types of vegetables, including lettuce. To get good results, both in quality and quantity for lettuce, one of the efforts that can be taken apart from the provision of Growth Regulatory Substances (ZPT). With a good ZPT, good lettuce plants will be produced both in terms of quality and quantity. One of these ZPT is Moringa leaf extract. The purpose of this study was to determine the effect of the treatment of Moringa leaf extract concentration on the growth and yield of lettuce plants and to determine the concentration of Moringa leaf extract which is best used to increase the growth and yield of lettuce plants. The study was conducted at the STIPER Experimental Garden Petra Baliem Wamena Jayawijaya Regency at an altitude of 1664 meters above sea level. The study was conducted in June to September 2017. Materials used were: Lettuce Seeds, Moringa Leaves, Polybags, Soil. The tools used are: Digital Scales, Stationery, Blenders, Strainer, Measuring Cup. The study used a Completely Randomized Design (CRD) consisting of 4 levels of concentration of Moringa leaf extract treatment and 4 replications. The level of treatment of Moringa leaf extract concentration are: K0: 0\% concentration ( $300 \mathrm{ml}$ water without Moringa leaf extract); K1: $25 \%$ concentration ( $75 \mathrm{ml}$ of Moringa leaf extract $+225 \mathrm{ml}$ of water); $\mathrm{K} 2: 50 \%$ concentration ( $150 \mathrm{ml}$ moringa leaf extract $+150 \mathrm{ml}$ water); $\mathrm{K} 3: 75 \%$ concentration ( $225 \mathrm{ml}$ moringa leaf extract $+75 \mathrm{ml}$ water). In this study there were 4 (four) treatments and 4 (four) replications so that there were 16 plots / units of the experiment. The results of this study are: 1) The concentration of Moringa leaf extract can affect lettuce height at 1 week, 2 weeks and 4 weeks; number of leaves of lettuce at 2 weeks, 3 weeks and 4 weeks; and fresh weight of lettuce. and 2) The best concentration of Moringa leaf extract for growth and yield of lettuce is $\mathrm{K} 2$ concentration (50\% concentration).
\end{abstract}

Keywords: concentration, moringa leaf extract, lettuce

\begin{abstract}
ABSTRAK
Sayuran merupakan salah satu produk pertanian yang sangat dibutuhkan dan tanaman semusim ini merupakan tanaman yang pada umumnya relatif sedikit waktu tanamnya. Dari berbagai jenis sayuran itu, termasuk didalamnya adalah sayur selada. Untuk memperoleh hasil yang baik, baik secara kualitas maupun kuantitas bagi tanaman selada, salah satu usaha yang dapat ditempuh selain dengan pemberian Zat Pengatur Tumbuh (ZPT). Dengan ZPT yang baik, maka akan dihasilkan tanaman selada yang bagus baik dari segi kualitas maupun kuantitasnya. Salah satu ZPT tersebut adalah ekstrak daun kelor. Tujuan penelitian ini adalah Untuk mengetahui pengaruh perlakuan konsentrasi ekstrak daun kelor terhadap pertumbuhan dan hasil tanaman selada dan Untuk mengetahui konsentrasi ekstrak daun kelor yang paling baik digunakan untuk meningkatkan pertumbuhan dan hasil tanaman selada. Penelitian dilaksanakan di Kebun Percobaan STIPER Petra Baliem Wamena Kabupaten Jayawijaya pada ketinggian tempat 1664 mdpl. Penelitian dilaksanakan pada bulan Juni s/d September 2017. Bahan yang digunakan adalah : Benih Selada, Daun Kelor, Polybag, Tanah. Alat yang digunakan adalah : Timbangan Digital, Alat Tulis, Blender, Saringan, Gelas Ukur. Penelitian menggunakan Rancangan Acak Lengkap (RAL) yang terdiri atas 4 aras perlakuan konsentrasi ekstrak daun kelor dan 4 ulangan. Adapun aras perlakuan konsentrasi ekstrak daun kelor adalah : K0: Konsentrasi 0\% ( $300 \mathrm{ml}$ air tanpa ekstrak daun kelor ); K1:Konsentrasi 25\% ( $75 \mathrm{ml}$ ekstrak daun kelor $+225 \mathrm{ml}$ air ); K2: Konsentrasi 50\% ( $150 \mathrm{ml}$ ekstrak daun kelor + $150 \mathrm{ml}$ air ); K3: Konsentrasi 75\% ( $225 \mathrm{ml}$ ekstrak daun kelor $+75 \mathrm{ml}$ air ). Pada penelitian ini ada 4 (empat) perlakuan dan 4 (empat) ulangan sehingga terdapat 16 petak/unit percobaan. Hasil dari penelitian ini adalah : 1) Konsentrasi ekstrak daun kelor dapat mempengaruhi tinggi tanaman selada umur 1 minggu, 2 minggu, dan 4 minggu; jumlah daun tanaman selada umur 2 minggu, 3 minggu dan 4 minggu; dan bobot segar tanaman selada. dan 2) Konsentrasi ekstrak daun kelor yang terbaik bagi pertumbuhan dan hasil tanaman selada adalah konsentrasi K2 (konsentrasi 50\%).

Kata kunci : konsentrasi, ekstrak daun kelor, selada
\end{abstract}




\section{PENDAHULUAN}

Selada adalah sayuran yang sering digunakan sebagai pelengkap atau lalapan atau sering pula digunakan dalam hiasan suatu makanan. Mengusahakan tanaman selada ini dapat dijadikan sebagai prospek bisnis, misalnya di daerah Cibogo Kabupaten Lembang Provinsi Jawa Barat dimana telah dijalankan usaha kerjasama antara jaringan restoran fast food bertaraf Internasional seperti Mc Donald dengan petani setempat (Haryanto, 2006). Hal ini juga dapat menjadi peluang bisnis yang bagus bagi petani di Kabupaten Jayawijaya untuk membudidayakan selada.

Untuk memperoleh hasil yang baik, baik secara kualitas maupun kuantitas bagi tanaman selada, salah satu usaha yang dapat ditempuh adalah dengan pemberian Zat Pengatur Tumbuh (ZPT) salah satunya adalah ekstrak daun kelor. Dengan ZPT yang baik, maka akan dihasilkan tanaman selada yang bagus baik dari segi kualitas maupun kuantitasnya

\section{BAHAN DAN METODE}

\section{Alat dan Bahan}

Penelitian dilaksanakan di Kebun Percobaan STIPER Petra Baliem Wamena Kabupaten Jayawijaya pada ketinggian tempat 1664 mdpl. Penelitian dilaksanakan pada bulan Juni s/d September 2017. Bahan yang digunakan adalah: Benih Selada, Daun Kelor, Polybag, Tanah sedangkan alat yang digunakan adalah : Timbangan Digital, Alat Tulis, Blender, Saringan, Gelas Ukur.

\section{Metode Penelitian}

Penelitian menggunakan Rancangan Acak Lengkap (RAL) yang terdiri atas 4 aras perlakuan konsentrasi ekstrak daun kelor dan 4 ulangan. Adapun aras perlakuan konsentrasi ekstrak daun kelor adalah :

K0 : Konsentrasi 0\% ( $300 \mathrm{ml}$ air tanpa ekstrak daun kelor )

K1 : Konsentrasi 25\% ( $75 \mathrm{ml}$ ekstrak daun kelor $+225 \mathrm{ml}$ air )

K2 : Konsentrasi 50\% ( $150 \mathrm{ml}$ ekstrak daun kelor $+150 \mathrm{ml}$ air )

K3 : Konsentrasi 75\% ( $225 \mathrm{ml}$ ekstrak daun kelor $+75 \mathrm{ml}$ air )

Pada penelitian ini ada 4 (empat) perlakuan dan 4 (empat) ulangan sehingga terdapat 16 petak/unit percobaan. Tiap unit percobaan terdiri dari 5 tanaman, maka total tanaman yang dibutuhkan adalah sebanyak 80 tanaman. Tiap unit percobaan diambil 3 tanaman sampel sehingga total tanaman sampel adalah 48 tanaman

\section{HASIL DAN PEMBAHASAN}

\section{A. Rerata Tinggi Tanaman}

Tabel 1 . Rerata Tinggi Tanaman

\begin{tabular}{lcccc}
\hline Perlakuan & \multicolumn{4}{c}{ Pengamatan Minggu ke- } \\
\cline { 2 - 5 } & 1 & 2 & 3 & 4 \\
\hline K0 & $0,49 \mathrm{~b}$ & $1,52 \mathrm{~d}$ & 2,63 & $2,94 \mathrm{~b}$ \\
$\mathrm{~K} 1$ & $1,00 \mathrm{a}$ & $2,12 \mathrm{~b}$ & 3,54 & $3,83 \mathrm{a}$ \\
$\mathrm{K} 2$ & $1,00 \mathrm{a}$ & $1,98 \mathrm{c}$ & 3,61 & $3,96 \mathrm{a}$ \\
K3 & $1,00 \mathrm{a}$ & $3,50 \mathrm{a}$ & 4,11 & $4,35 \mathrm{a}$ \\
\hline BNT & 0,253 & 0,218 & - & 0,47 \\
\hline
\end{tabular}

Keterangan : nilai sekolom yang diikuti dengan huruf yang sama menunjukkan tidak berbeda nyata uji BNT 5\%

Pada tabel 3 diatas dapat kita lihat bahwa pada minggu pertama, kedua dan keempat konsentrasi ekstrak daun kelor berpengaruh nyata terhadap tinggi tanaman selada, akan tetapi pada minggu ketiga ekstrak daun kelor tidak berpengaruh terhadap tinggi tanaman. Tinggi tanaman pada konsentrasi K3 (konsentrasi 75\%) tampak bahwa tanaman paling tinggi apabila dibandingkan dengan tinggi tanaman pada konsentrasi lainnya. Hal ini disebabkan karena semakin optimal suatu konsentrasi atau semakin banyak nutrisi yang diberikan, maka akan menghasilkan kandungan unsur hara yang optimal pula untuk memacu pertumbuhan tinggi suatu tanaman. Hal ini sesuai dengan pendapat Kartika (2013) yang mengatakan bahwa konsentrasi tertinggi dari perlakuan akan menghasilkan unsur hara paling optimal untuk pertumbuhan tanaman. Pada minggu pertama dan minggu keempat tampak bahwa antara konsentrasi K1 (konsentrasi 25\%), K2 (konsentrasi 50\%) dan K3 (konsentrasi 75\%) tidak berbeda nyata. Ini menunjukkan bahwa pada minggu pertama tanaman belum membutuhkan nutrisi dalam jumlah yang optimal bagi pertumbuhan vegetatifnya. Hal ini sesuai dengan pendapat Ragil (2016) yang mengatakan bahwa tinggi tanaman bayam yang diperlakukan dengan konsentrasi daun kelor pada minggu ketiga tidak berbeda nyata. 
B. Rerata Jumlah Daun

Tabel 2 . Rerata Jumlah Daun

\begin{tabular}{lcccc}
\hline \multirow{2}{*}{ Perlakuan } & \multicolumn{4}{c}{ Pengamatan Minggu ke- } \\
\cline { 2 - 5 } & 1 & 2 & 3 & 4 \\
\hline K0 & 2,00 & $2,74 \mathrm{~b}$ & $4,91 \mathrm{~b}$ & $7,08 \mathrm{c}$ \\
K1 & 3,00 & $3,58 \mathrm{a}$ & $5,49 \mathrm{~b}$ & $8,33 \mathrm{~b}$ \\
K2 & 2,50 & $3,74 \mathrm{a}$ & $6,33 \mathrm{a}$ & $8,74 \mathrm{~b}$ \\
& & & & \\
K3 & 2,75 & $4,66 \mathrm{a}$ & $6,83 \mathrm{a}$ & $9,91 \mathrm{a}$ \\
\hline \multicolumn{1}{c}{ BNT } & - & 0,59 & 0,62 & 0,511
\end{tabular}

Keterangan : nilai sekolom yang diikuti dengan huruf yang sama menunjukkan tidak berbeda nyata uji BNT 5\%

Rerata jumlah daun pada tabel 2 diatas tampak bahwa konsentrasi ekstrak daun kelor berpengaruh nyata terhadap jumlah daun tanaman selada pada minggu kedua sampai dengan minggu keempat. Akan tetapi pada minggu pertama tampak tidak berbeda nyata. Ketidak berpengaruh nyatanya konsentrasi ekstrak daun kelor pada minggu pertama karena pada minggu ini tanaman masih sangat muda sehingga penyerapan nutrisi masih sangat rendah. Pada tabel diatas dapat dilihat juga bahwa konsentrasi K3 (konsentrasi 75\%) menghasilkan jumlah daun yang lebih banyak apabila dibandingkan dengan konsentrasi lainnya. Hal ini disebabkan karena semakin tinggi konsentrasi maka kandungan nutrisi yang diserap akan semakin optimal sehingga secara tidak langsung akan meningkatkan pertumbuhan suatu tanaman dalam hal ini jumlah daun. Gurning (2009) berpendapat bahwa semakin tinggi konsentrasi pupuk akan cenderung meningkatkan pertumbuhan suatu tanaman karena kandungan nutrisi yang optimal.

C. Rerata Bobot Segar

Tabel 3. Rerata Bobot Segar (gram)

Perlakuan Rerata Bobot Segar

\begin{tabular}{|c|c|}
\hline K0 & $12,56 \mathrm{c}$ \\
\hline K1 & $17,62 \mathrm{~b}$ \\
\hline K2 & $33,29 \mathrm{a}$ \\
\hline K3 & $30,33 \mathrm{a}$ \\
\hline BNT & 4,07 \\
\hline
\end{tabular}

Keterangan : nilai sekolom yang diikuti dengan huruf yang sama menunjukkan tidak berbeda nyata uji BNT 5\%

Pada tabel 3 diatas pada rerata bobot segar tanaman dapat kita lihat bahwa konsentrasi ekstrak daun kelor berpengaruh nyata terhadap bobot segar tanaman. Hal ini berarti bahwa ekstrak daun kelor dapat meningkatkan bobot segar tanaman. Ini sesuai dengan pendapat Dudi (2012) yang mengatakan bahwa Penyemprotan daun tanaman dengan ekstrak hormon pertumbuhan daun kelor menghasilkan beberapa efek yang sudah dikenal seperti, vigor lebih kuat, batang, akar, berat daun dan buah lebih besar dan kandungan kadar gula yang lebih tinggi, dll. Dalam tabel diatas juga dapat dilihat bahwa K2 (konsentrasi 50\%) dan K3 (konsentrasi $75 \%$ ) tidak berbeda nyata akan tepai berbeda nyata dengan konsentrasi K1 (konsentrasi 25\%) dan K0 (konsentrasi 0\%). Bobot segar suatu tanaman sangat dipengaruhi oleh penyerapan unsur hara dan penimbunan hasil fotosintesis dalam tumbuhan. Semakin optimal unsur hara dalam pupuk akan semakin menambah berat basah tanaman

\section{KESIMPULAN}

Berdasarkan hasil penelitian dapat disimpulkan sebagai berikut :

1. Konsentrasi ekstrak daun kelor dapat mempengaruhi tinggi tanaman selada umur 1 minggu, 2 minggu, dan 4 minggu; jumlah daun tanaman selada umur 2 minggu, 3 minggu dan 4 minggu; dan bobot segar tanaman selada.

2. Konsentrasi ekstrak daun kelor yang terbaik bagi pertumbuhan dan hasil tanaman selada adalah konsentrasi K2 (konsentrasi 50\%).

\section{DAFTAR PUSTAKA}

Gurning, 2009. Pertumbuhan Dan Produksi Tanaman Selada (Lactuca Sativa L.) Pada Berbagai Tingkat Dosis Pupuk Npk Dan Pupuk Mikro. Skripsi. Jurusan Agronomi Universitas Sumatera Utara

Haryanto, 2006. Sawi Dan Selada.Penebar Swadaya. Jakarta

Kartika, 2013. Pengaruh Organik Cair Daun Kelor Terhadap Pertumbuhan Tanaman Pakcoy Yang Ditanam Secara Hidroponik. Skripsi. Fakultas Biologi Universitas Sriwijaya.

Ragil, 2016. Pemanfaatan Daun Kelor Dan Bonggol Pisang Sebagai Pupuk Organik Cair Untuk Pertumbuhan Tanaman Bayam (Amaranthus Sp.). Skripsi Universitas Muhammadiyah Surakarta 